\title{
"A dança de centauras" \\ e o legado romântico nas \\ mãos de Francisca Júlia
}

\section{Vagner Camilo}

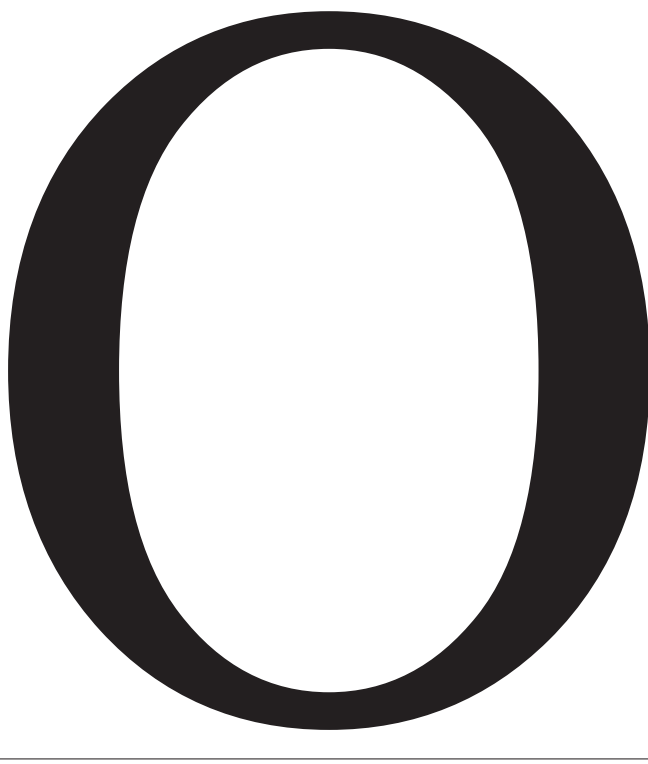

riginalmente, o propósito desta abordagem era rastrear a herança romântica na obra de Francisca Júlia, que se deixa flagrar, de forma mais imediata, nas traduções dos Lieder de Goethe e dos números do Intermezzo, de Heinrich Heine, constantes de seu livro de estreia, Mármores (1895). A discussão, entretanto, seria extensa demais para um só ensaio, até porque precisaria resgatar a polêmica em torno das

VAGNER CAMILO é professor associado de Literatura Brasileira da FFLCH/USP e autor de, entre outros, $A$ modernidade entre tapumes: da poesia social à inflexão neoclássica na lírica brasileira moderna (Ateliê Editorial/Fapesp). 
traduções ${ }^{1}$, que data desde a primeira recepção do livro. Além do limite imposto pela extensão, havia a barreira maior da língua alemã, que me impedia julgar da pertinência das traduções, embora meu interesse, no que concerne a Heine, estivesse, desde sempre, circunscrito ao famoso recurso que notabilizou o dito romântico défroqué2: "O famoso 'cinismo' dos desfechos irônicos que destroem o lirismo melancólico do começo do poema" (Carpeaux, 1987, v. 5, p. 1.364) pondo em xeque poses ou gestos românticos convertidos em clichês, repisados à exaustão não só por epígonos, mas até pelos prógonos, contrariando o programa estético da escola, que primava pelo novo, original, único. Esse é um capítulo ainda a se escrever na história do Romantismo no Brasil, que partiria não da versão de Varnhagen, o primeiro que se supõe ter traduzido um poema de Heine para o português, embora sem entender

1 Emílio Strauss, em folhetins do Tagblatt de São Paulo, sob o título "Eine brasilianische Heine-Meberseizung", entre 28 de junho e 8 de julho de 1894 , conforme nota do prefaciador, João Ribeiro, que dá informações sobre o contexto de tradução e repercussão em: Silva (2020).

2 Angelloz considera a ironia, o desdobramento da subjetividade lírica, a ênfase no detalhe verista como traços de modernidade da poesia de Heine, o que supostamente justificaria o défroqué... (ver Angelloz, 1949, pp. 309 e segs).

3 Diz ainda Rosenfeld (1969, pp. 189-90) sobre tais desfechos: "O caso frequente de Heine que [...] num rasgo de sincera autorrevelação da própria duplicidade do intelectual 'singelo', muitas vezes desfaz, nos últimos versos, pelo disfarce da ironia, o disfarce do tom popular mantido através do poema. Atitude geralmente criticada como ápice da falsidade íntima, mas que, bem ao contrário, é uma tentativa de sinceridade consigo mesmo que pressupõe a qualidade superior da boa-fé - essa sim uma qualidade moral (é verdade que Sartre considerava a mauvaise foi inerente ao homem)". o alcance crítico desse recurso característico da poesia do autor de Reisebilder. E isso mesmo tendo frequentado o salão berlinense de sua parente Rahel Varnhagen, que acolhia muitas das discussões e propostas disseminadas por alguns dos grandes nomes do Romantismo alemão, incluindo Heine, um dos frequentadores.

Em vez da tradução de Varnhagen, as de Gonçalves Dias seriam o verdadeiro marco, vertidas do alemão provavelmente nos anos $1850^{4}$ e atentas aos fins visados por tais desfechos irônicos. Elas passaram despercebidas até mesmo a Maria Manuela Gouveia Delille, em seu imenso levantamento sobre a recepção de Heine em Portugal (Delille, 1984), que arrisca uma breve incursão pelo Brasil, registrando apenas a versão de Varnhagen como uma das primeiras em língua portuguesa vertidas diretamente do original, ainda que sem atentar à particularidade trazida pelo poeta alemão. No mais, a estudiosa registra as versões francesas em prosa poética de Gérard de Nerval como sendo as que divulgaram, nas décadas de 1840 e 1850 , nas páginas da Revue des Deux Mondes, a obra do poeta alemão, tanto em Portugal, quanto no Brasil. Ainda em 1858, as traduções de Lúcio de Mendonça traíam o registro simples e incisivo de Heine no trato com o tema do amor traído ao empregar um tom grave e uma adjetivação romântico-sentimental, que anulava por

4 Durante estada na Alemanha, em carta de 1858, endereçada ao Barão de Capanema, Gonçalves Dias diz traduzir "uma meia dúzia de poesias alemãs, de mistura com outras de outras línguas", o que deve incluir os poemas de Heine (ver Gonçalves Dias, 1964, p. 240). 
completo a nota dissonante instituída pela ironia marcante no original.

Delille ignora certo protagonismo de Gonçalves Dias na tradução de Heine, atento a tal registro dissonante. É verdade que, antes dele, Álvares de Azevedo, ao compor "Relógios e beijos" - traduzido de Henrique Heine -, resgatou o traço humorístico marcante nos versos do poeta. A germanista portuguesa também desconhece o caso do autor da Lira dos vinte anos e não caminha adiante com seu rastreamento no Brasil, a ponto de alcançar as de Francisca Júlia, que inclusive chegou a traduzir um poema já vertido pelo poeta maranhense. Seguem as duas versões para que o leitor possa confrontar:

\section{Gonçalves Dias:}

"Tenho veneno nos versos!...

Pois que menos pode ser?

Era eu quase uma criança,

Quando mo deste a beber.

Tenho veneno nos versos!...

Pois seja: veneno têm.

Também tenho serpes n'alma

E a ti, amada, também"5.

\section{Francisca Júlia:}

"Meus cantos, cujo treno

Minha alma escuta, amargurada e triste,

São repassados de letal veneno:

De outra forma não pode ser, querida,

Porque tu espargiste

Sobre a modesta flor da minha vida

O orvalho do veneno.

5 Gonçalves Dias, 1957, p. 1.020.
Meu canto, cujo treno

Qualquer sorriso em lágrimas transforma, São repassados de letal veneno;

Não pode ser, entanto, de outra forma,

Porque, em meio das cousas mais singelas

Que tenho n'alma, agitam-se, frementes,

Implacáveis serpentes...

E tu, formosa amante, és uma delas!"6

A versão de Gonçalves Dias parece ganhar força pela capacidade de síntese, pelo tom mais prosaico, pela escolha das populares redondilhas e, evidentemente, pelo referido desfecho irônico, que mais sugere do que diz, ao passo que a "tradução literal rigorosa" de Francisca Júlia, ao prolongar demasiadamente estrofes e versos decassilábicos (alternados com hexassílabos) e explicitar a associação final da amada com a serpente, comprometendo o humor, revela, talvez, os "perigos e as desvantagens da paráfrase", que lhe apontava João Ribeiro (2020) no Prefácio ao livro de estreia. O devido confronto com o original alemão poderia dizer mais das propriedades e impropriedades de ambas as traduções. Todavia, seja como for, a de Francisca Júlia não deixa de registrar uma nota de ironia (mesmo que enfraquecida) e de ser um capítulo relevante na recepção da obra do poeta alemão, cujos traços característicos atravessaram o século XIX e chegaram ao XX, tendo contribuído, talvez, para se forjar certa dicção marcante no Modernismo, produto dessa aliança entre o prosaico e o humorístico, incluindo-se

6 Na edição mais recente do livro de estreia da poeta, o organizador chama a atenção para o erro - devidamente corrigido - na edição príncipe, que registrava A. Heine em vez de H. Heine (ver Silva, 2020, pp. 9, 63 e 67). 
aí os famosos desfechos irônicos (Bandeira poderia ser uma referência nesse sentido).

Além dessas traduções, haveria outros momentos da obra de Francisca Júlia que instituem um diálogo direto com o legado romântico, a exemplo de poemas como "A uma criança" (incluído em Mármores e, depois, em Livro da infância), definido como "imitação de Hugo", além da evocação em epígrafe de nomes representativos do movimento, como Lamartine, na abertura de "Prece", e novamente Goethe, em "Alma e destino". Destaque-se, ainda, a exploração, pela poeta, de um gênero poético caro aos românticos: as baladas, valendo lembrar, entre elas, "D. Alda", cujo subtítulo indica: "Lied moderno".

Afora as traduções e imitações, seria preciso, ainda, rastrear distintos momentos da poesia de Francisca Júlia concebidos a partir do diálogo evidente com tal legado, o que é mais importante. Por ora, a fim de ilustrar essa interlocução produtiva, proponho ater-me a um de seus maiores poemas e uma das realizações mais felizes de nosso Parnasianismo, como foi reconhecido desde os primeiros intérpretes ${ }^{7}$, passando por um modernista radical, em tese avesso à escola parnasiana, como Mário de Andrade, até interpretações posteriores.

7 Veja, nas recensões recolhidas na edição de 1921 de Esphinges, o destaque dado a "Dança de centauras" no conjunto do livro por intérpretes como Vicente de Carvalho (que, "maravilhado", fala em "impressões de deslumbramento"); Leal de Souza (que louva a lapidaria exata em que palpita o poema, o rijo vigor marmóreo e o cromatismo da música estuante das estrofes); e, entre outros, Coelho Netto, a quem é dedicado o poema, que traz observações relevantes sobre esse "primor" de poema, "pequenina joia", "lindo episódio com que Praxíteles ornaria ricamente um frontão" e seu "remate de uma inesperada beleza" (ver Silva, 1921, pp. XII-XXII).

\section{"DANÇA DE CEnTAuras}

\section{A Coelho Netto}

Patas dianteiras no ar, bocas livres dos freios, Nuas, em grita, em ludo, entrecruzando as [lanças, Ei-las, garbosas vêm, na evolução das danças Rudes, pompeando à luz a brancura dos seios.

A noite escuta, fulge o luar, gemem as franças; Mil centauras a rir, em lutas e torneios, Galopam livres, vão e vêm, os peitos cheios De ar, o cabelo solto ao léu das auras mansas.

Empalidece o luar, a noite cai, madruga... A dança hípica para e logo atroa o espaço O galope infernal das centauras em fuga:

É que, longe, ao clarão do luar que empalidece, Enorme, aceso o olhar, bravo, do heroico braço Pendente a clava argiva, Hércules aparece..." (Silva, 1921, pp. 11-2).

O poema guarda algo similar às celebrações noturnas do Monte Brocken, no Fausto. O episódio goethiano remete à Walpurgisnacht ou Hexennacht ("Noite das Bruxas", em que elas comemoram a chegada da primavera), véspera da festa cristã de Santa Valburga, abadessa anglo-saxônica do século VIII que foi missionária na Alemanha. A gênese de tal festividade está em antigas celebrações pagãs, votadas à invocação das divindades da fertilidade na noite de 30 de abril, data da transição da primavera ao verão, quando se homenageia Belenos (deus celta das energias renovadoras do sol ou fogo), acendendo fogueiras a fim de revigorar cidades e habitantes com a fumaça. Algumas localidades adotaram tal festividade para fins de feitiçaria. Foi, 
então, absorvida com a chegada do Cristianismo, atribuindo origens vagas relacionadas a um suposto aniversário de Satanás. Em toda a Europa e Ásia, acreditava-se que, em maio (consagrado aos ancestrais na antiga Roma), os fantasmas faziam incursões entre os vivos. Na Antiguidade e no correr da Idade Média, evitava-se casar nesse mês para não correr o risco de contrair matrimônio com um ser do outro mundo. No norte europeu, corria a crença em uma divindade protetora das bruxas, reunindo-as anualmente em uma montanha. Tais concílios, confundidos com os de seres míticos, ocorriam em uma noite de maio, relacionada às Valquírias. Em algumas versões lendárias, consta que as bruxas saíam de casa em procissões, lembrando a crença de que, em certas noites, pode-se escutar ruídos produzidos por exércitos sinistros, de almas e espíritos. Os concílios transcorriam no pico mais elevado da cordilheira Harz (o referido Monte Brocken). As bruxas untavam-se com unguentos, à base de gordura de gato, lobo ou leite de burra e saíam montadas em vassouras, voando pelos ares para celebrarem suas festas com demônios (que, para transportá-las a pontos distantes na Alemanha, metamorfoseavam-se em cabras, porcos, bezerros e outros animais semelhantes e passavam a noite toda de maio jogando, festejando e dançando). Com o transcorrer do tempo, a data foi aproximada à celebração católica da canonização de Santa Valburga - e, vale registrar, durante a Noite de Walpurgis de 1776 foi fundada a seita Illuminati nas florestas da Baviera.

Para conceber suas versões, Goethe parece ter colhido inspiração na famosa cena das bruxas de Macbeth (que nossa poeta também devia bem conhecer). As celebrações se estendem por toda a noite - "lugar das revelações", como diria Novalis - até o romper da alva. Mais especificamente, com as 12 badaladas do relógio, os espíritos, formas elementares e seres os mais fantásticos abandonam seus redutos a fim de se reunirem e celebrarem numa clareira ou monte as orgias da confusão, que se estendem por toda a noite até o despontar da aurora, quando soa, por assim dizer, o toque de recolher, obrigando-os a se dispersarem, partirem em disparada e buscarem refúgio nos cantos mais recônditos da natureza.

Simbolicamente, o episódio ilustra à perfeição o imaginário romântico em torno da noite como domínio do mistério, do sobrenatural, da anormalidade e do inconsciente liberto em sonho ou, no limite extremo, em pesadelo, por oposição à luz do dia, criticamente associada a (neo) clássicos, imbuídos de certo racionalismo e dualismo cartesiano. Contra a luz da razão patrocinada pelo Aufklärung, que a tudo buscava esquadrinhar e revelar de modo distinto, compartimentalizado e abstrato, os românticos lançaram seu apelo à "divina confusão" da noite (Schelling), cuja tônica era oferecida pela "mescla" ou pelo híbrido do que os clássicos trabalhavam em separado. Para os românticos, a Natureza só começa a falar aos homens quando as sombras da noite se estendiam pelo vale, convidando não ao recolhimento e ao sono reparador (tal como a concebe o burguês, insensível a seu apelo), mas à contemplação da - ou participação na desforra das forças elementares, das pulsões, sentimentos e existências represadas, reprimidas ou ofuscadas pela luz diurna da razão e pelas disjunções civilizadas. A 
culminância dessa ordem de experiência dá-se à meia-noite, quando a fantástica folia irrompia em meio a clareiras, vales ou montes. Assim ocorria com a orgia mefistofélica no Monte Brocken, a noite no Monte Calvo de Mussorgsky e, decerto, o espaço natural em que se dá o ápice da dança marcial das centauras, que poderiam entoar, como os elfos de conhecida canção do mesmo Goethe, que encenam a situação paradigmática do noturno valpurgiano:

"À meia-noite, quando já os homens dormem, É então para nós que a lua brilha,

Que para nós a estrela começa a cintilar; Vagueamos e cantamos

E é então que gostamos de dançar.

À meia-noite, quando já os homens dormem, Sobre prados, junto aos alnos,

Buscamos o nosso lugar,

Vagueamos e cantamos

E dançamos um sonho de luar"

(Goethe, 1979) ${ }^{8}$.

A "Noite de Walpurgis" foi das passagens do Fausto mais emuladas por românticos de todos os lugares e de toda cepa. Só para citar alguns exemplos, alinhavam-se a ela poemas de Victor Hugo, como "La ronde du sabbat" (Odes e ballades, 1826) e "Les djinns" (Les orientales, 1828); de Theophile Gautier, nos versos de "Albertus, l'âme et le péché" (1833); e de Espronceda, em El diablo mundo (1841). Entre nós, são

8 A exaltação da hora noturna reaparece em outro poema de Francisca Júlia, "A noite", dedicado a Wenceslau de Queiroz e incluído em Esphinges (Silva, 1921, pp. 43-4). Em outros, sob o mesmo título, porém, a noite aparece perpassada de notas melancólicas, lutuosas. conhecidas as recriações geniais de Bernardo Guimarães (que mobiliza seres do anedotário popular e da fauna local em "A orgia dos duendes" para encenar uma versão cômico-grotesca e perversa do nacionalismo romântico, na qual outro parnasiano reconheceu o registro de "cerimônias da demonologia brasileira""9); Sousândrade, no "Tatuturema", do Guesa errante, com visada crítica ainda mais ampla e cuja dívida para com o episódio goethiano é atestada pelo poeta maranhense em sua Memorabilia; e Joaquim Serra, que, em "Ecletismo", encena o embate entre Realismo e Romantismo promovido pela Questão Coimbrã, associando a dimensão agônica do episódio goethiano ao bíblico Vale de Josafá, onde ocorreria o julgamento final, conforme o Livro de Joel. Talvez familiarizada não só com a obra de Goethe, mas com as liberdades das apropriações francesas e locais como essas, Francisca Júlia podia ter em vista o "pandemônio fáustico", como diria outro poeta-tradutor de Goethe (Haroldo de Campos), para ajustá-lo a um fim muito distinto do original e de todas essas recriações - embora possa ter colhido alguma inspiração para suas centauras em certas figuras míticas e lendárias aproximadas do ritual original.

O que me parece curioso é a poeta paulista reorientar o diálogo intertextual com o famoso episódio goethiano a uma nova demanda de expressão poética ou dramática, que concerne especificamente - se pu-

9 Para uma análise do poema de Guimarães e dessa vertente que parte da noite valpurgiana, ver Camilo (1987, pp. 159-79). O referido poeta parnasiano é Olavo Bilac, que fala do poema em sua conferência de 1905 sobre o diabo (ver Bilac, 1906, pp. 113-5). 
desse resumir assim, com todo o risco de reducionismo - a uma questão de gênero, já assinalada por mais de um intérprete, embora de perspectivas algo diversas. Afinal, o que se celebra por meio da "dança hípica", cuja evolução funde o ritual lúdico com o entrecruzar de lanças, é a encenação de um embate belicoso, aludindo a uma prática tida geralmente como masculina, embora na tradição clássica e mítica já despontassem mulheres guerreiras, como as amazonas ou mesmo (de modo diverso) as valquírias na mitologia nórdica ${ }^{10}$. No imaginário ocidental, entretanto, a prática de guerra ficou, de certo modo, associada ao universo masculino. Já no poema, são as mulheres que se apropriam dos instrumentos de guerra: as lanças fálicas, de que se apossam as mãos femininas, prestam-se a outra destinação. Desvirtuando a finalidade primeira, em vez de dominação, sujeição e morte de um adversário, visam ao prazer lúdico (os versos falam em "ludo"), ao júbilo, à celebração e à afirmação femininos. É com esse intuito que as lanças são projetadas não para a frente, como na posição de ataque das antigas falanges guerreiras, mas a 45 graus, inclinadas e entrecruzadas, que também não representa uma po-

10 Emmanuel Santiago (2014) evocou as amazonas a propósito das centauras de Francisca Júlia, mas sem maiores considerações, assim como Coelho Netto, a quem é dedicado o poema, preferiu evocar a cavalgada das valquírias como termo de comparação. De fato, como se trata de mulheres guerreiras, não raro figuradas a galope, compreende-se, em dada medida, a associação, embora as amazonas não sejam seres híbridos como as centauras. Não se pode esquecer, todavia, a procedência do mito do centauro, do grego kentauros ("matador de touros"), que teve origem com viajantes que observavam vaqueiros sempre a cavalo na região da Tessália. Pela ilusão de ótica, a visão de homens a cavalo, por instantes, sugeria a impressão de formarem um único ser... sição de prontidão, como se estivessem a se precaver ou proteger-se de um ataque pelo alto. Sugerem mais um gesto cúmplice, buscando firmar uma aliança entre pares, entre iguais. Portanto, não se trata, a meu ver, de terçar armas seriamente, dançando e lutando "numa atmosfera guerreira, até mesmo violenta", como quer Emmanuel Santiago (2014). Parece-me, muito mais, que as centauras encenam o gesto guerreiro para prazer próprio ou mesmo como paródia, divertindo-se à custa dele. Ainda que "rudes", são danças, encenação como jogo, "ludo"... Não por acaso, dizem os versos, são "mil centauras a rir, em lutas e torneios". Trata-se de expor à irrisão aquilo que mobiliza o total empenho masculino seja ao buscar medir força e coragem, seja ao dominar, destruir e matar.

Assim, com as lanças em punho, elas encenam uma afirmação libertária, à sombra da noite, tendo a Lua (esta também uma entidade mítica feminina) por testemunha e cúmplice. "Livre", aliás, é o único adjetivo que se repete no poema (versos 1 e 7). Associam-se a ele, ainda, outras imagens de livramento, soberania e desprendimento, como os brancos seios nus, iluminados pelo facho de luz da Lua cúmplice, "o cabelo solto ao léu das auras mansas", a "grita", as patas dianteiras no ar e, muito expressivamente, as "bocas livres dos freios", que se pode tomar em dois sentidos: sem o bridão (embora, no centauro, a dimensão animal tenha a ver com parte do corpo e não com a cabeça, que é humana) ou livres para dizer e gritar quanto ou o que quiserem, sem qualquer silenciamento, restrição ou punição.

Ocírroe, filha de Quíron, que possuía o dom da profecia herdado da mãe (a ninfa 


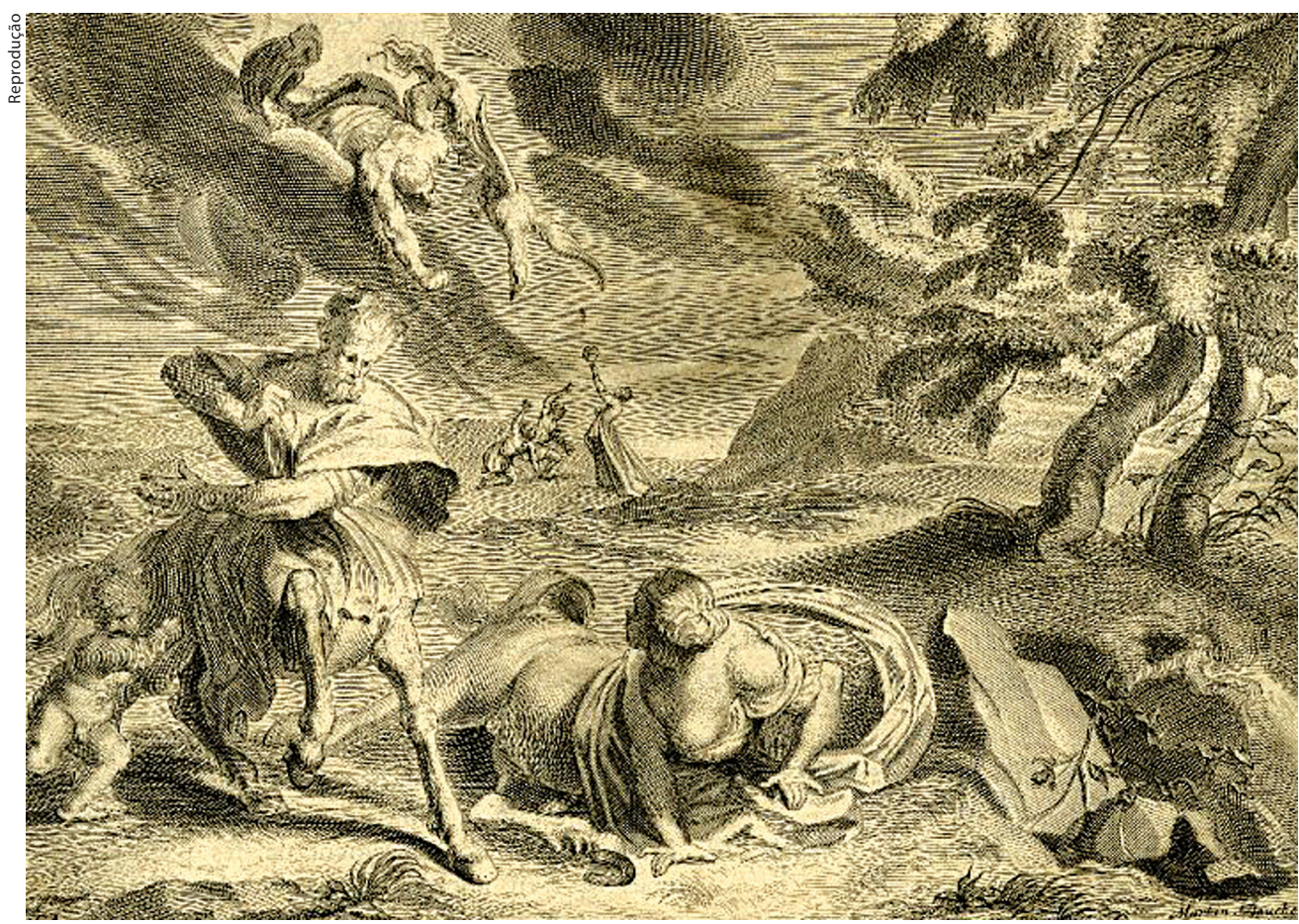

Martin Bouché, Ocírroe, 1677, British Museum

Cariclo), acabou sendo punida pelos deuses por empregá-lo inadvertidamente, sendo transformada, parcial ou integralmente, em figura equina e, com isso, perdendo sua capacidade de fala ${ }^{11}$. Já as centauras de Francisca Júlia podem falar ou gritar sem temer qualquer reprimenda ou castigo, pelo menos nessa hora noturna. Recuam, entretanto, diante da força opressora do dia e de Hércules, tido discutivelmente como herói civilizador, termo hoje polêmico nos estudos clássicos ${ }^{12}$.

$\mathrm{O}$ fato de as centauras fugirem em um "galope infernal" ao despontar do dia não se resume, como alguém poderia supor de pronto, a índice desabonador, seja de

11 Ver também, no mesmo passo, os relatos de Timothy Gantz (1993, pp. 168 e 734-5), sobre a transformação de Ocírroe em Hippo/Hippe, conforme Higino e outros. demonização, seja de fraqueza e covardia diante do inimigo ou opositor. Na verdade, sinaliza a consciência da força repressora que domina e conta com o beneplácito de toda ordem civil, moral e social.

Chamo a atenção para os contrastes evidentes não só entre o cenário e a hora eleita, como também entre os instrumentos de guerra: a noite (domínio do que vive à sombra, reprimido pelas leis da razão e da civilização), associada às centauras,

12 Conforme me advertiu Giuliana Ragusa, o rótulo de herói da cultura ou civilizatório aplicado a Héracles baseia-se em uma leitura facilitadora dos 12 trabalhos, por exemplo, associados ao puro e simples extermínio de seres bestiais, "exóticos" ou fora da "ordem". Ocorre que, conforme têm demonstrado diferentes intérpretes, tais trabalhos são muito mais complexos, entrelaçados que estão a mitos de busca e de teste, de fundação, mitos etiológicos de variada espécie e, entre outras questões, os que envolvem as relações dos homens com o mundo natural, com os deuses e a imortalidade. 
contrapõe-se ao dia que "madruga", aurora da razão opressora, que tudo esquadrinha, domina e controla, marcando a aparição de Hércules, o poderoso e destruidor inimigo da espécie híbrida que elas encarnam. O luar, que "fulgia" ao assistir à evolução da dança marcial das centauras, agora "empalidece" diante do olhar aceso e bravo do herói. Por fim, enquanto elas empunham as lanças entrecruzadas, o heroico braço de Hércules traz "a clava argiva” não erguida, mas "pendente"...

Importa retornar, ainda, a outro diálogo intertextual mais lembrado pela crítica, a fim de dimensionar o poema, na escolha do tema, em relação aos parâmetros fornecidos pelo próprio Parnasianismo europeu, particularmente francês. Além do que já revelara Mário de Andrade e outros críticos, Vera Lúcia Figueiredo Costa Rocha (1995) foi quem se deteve um pouco mais na interlocução do poema de Francisca Júlia com três poemas de Heredia: "Centaures et Lapithes", "Fuite de centaures" e "La centauresse".

No primeiro dos três, assistimos a uma celebração centáurica, digamos assim, só que bem diversa da do soneto de Francisca Júlia, embora possa tê-la inspirado. O poema herediano remonta à centauromaquia tessaliana, poetizando o episódio em que Pirítoo, rei dos Lápitas, antigo povo da Tessália, convida os centauros, seus irmãos por parte de pai (Ixião), para suas bodas com Hipodâmia. Embriagados, os centauros, a começar por seu líder, tomados pela violência e pela luxúria, tentaram raptar e violar a noiva e outras mulheres, provocando a reação dos tessálios e desencadeando um grande massacre. Com a ajuda de Teseu, esses últimos derrotam os centauros, finalmente expulsos da Tessália, indo se refugiar no Epiro. O embate emblematiza o confronto entre civilização e barbárie. Como se vê, é Teseu quem protagoniza a luta vitoriosa contra os centauros e não Héracles ou Hércules, conforme a versão herediana.

"Fuite de centaures" parece instituir o ato contínuo ao desfecho trágico e sangrento do festejo nupcial segundo o relato mítico, com a fuga dos centauros "embriagados de morte e rebelião/ rumo ao monte escarpado" que lhes serve de retiro, proteção e ponto de observação. Todavia, "o medo os precipita, eles sentem a morte próxima” e, saltando cobras e outros répteis, escalam "ravinas, torrentes, matagais, sem que nada os detenha", ao vislumbrar a luz da " lua cheia deslumbrante", "supremo espantalho,/ o horror gigantesco da sombra hercúlea" (Heredia, 1893, pp. 13-4). Novamente Hércules no lugar de Teseu. Desse poema, em particular, Francisca Júlia pode ter tomado o motivo da fuga, mas tratado de modo diverso e com outro propósito. Além disso, a aparição final e decisiva de Hércules nos dois poemas heredianos pode ser o elemento que liga o soneto da poeta brasileira a eles.

$O$ fato de Hércules não figurar nesse episódio mítico específico da centauromaquia tessálica não quer dizer, em absoluto, que ele deixe de confrontar os centauros no curso de sua carreira - mesmo não estando eles diretamente relacionados a nenhum dos 12 trabalhos hercúleos -, o que permite compreender o porquê da associação de sua figura ao inimigo ou exterminador da espécie nos poemas de Heredia e Francisca Júlia. Na busca pelo javali de Erimanto, terceiro de seus 12 trabalhos, Hércules encontra os centauros do Monte 
Pelião e acaba sendo involuntariamente responsável pela morte de Folo, assim como o foi pela de Quíron (o mais civilizado e superior de sua espécie $\left.{ }^{13}\right)$. Afora a morte acidental desses dois, há a de Nesso, que se dá em defesa da honra de Dejanira e que, indiretamente, é a causa da morte do próprio Hércules. Sabe-se, ainda, que este teria lutado com os centauros, expulsando-os do cabo Mália.

Diferentemente desses dois poemas heredianos, a aparição de Hércules não se dá em "La centauresse". Em compensação, esse terceiro soneto herediano tem a figura híbrida feminina, como no de Francisca Júlia. Segundo Costa Rocha, o poeta franco-cubano talvez tenha buscado alguma inspiração para essa figuração em tela de Louis Ménard e poema de Catulle Mendes ("Panteleïa"). Nesse soneto, em que "a inquietude humana se confunde com o instinto animal", Heredia explora o antigo tema da angústia amorosa da mulher-centauro abandonada pelo companheiro que se interessa por uma rival tida por "superior": uma "Mulher" vista como "meio de diminuir sua animalidade". Nada mais distinto, portanto, do soneto de Francisca Júlia em que as centauras bailam marcialmente, "orgulhosas de sua condição" (Rocha, 1995, p. 66). É possível desdobrar ainda mais tais considerações para avançar no entendimento da apropriação criativa que

13 "Dois centauros, todavia, Quíron e Folo, diferentes de outros pelo caráter, tinham origem também diferente. Quíron nasceu dos amores de Fílira e de Crono [...]; Folo é filho de Sileno e de uma ninfa dos freixos (uma Melíade). Quíron e Folo não têm o caráter selvagem dos seus congêneres; são hospitaleiros, benfazejos, amigos dos homens e não recorrem à violência" (Grimal, 2003, pp. 81-2).
Francisca Júlia fez desse poema herediano. Costa Rocha está certíssima ao dizer que o tema é antigo, e isso tanto na literatura quanto nas demais artes. Além dos nomes em que o próprio Heredia teria buscado inspiração para seu poema, pode-se evocar essa presença da centaura nos vários domínios, além dos relatos míticos. Assim, ao contrário do que supõe João Vicente ${ }^{14}$, a figura da centaura não se restringe ao poema herediano, remontando mesmo à Antiguidade, a exemplo de Luciano de Samósata (Das narrativas verdadeiras) e Ovídio (As metamorfoses e Ars amatoria) na literatura, sem desconsiderar possíveis figurações em baixos-relevos ou frontões de templos e edifícios. Posteriormente, inspirados pelos modelos clássicos e míticos, a centaura aparece em telas de Botticelli (detalhe do frontão do edifício de fundo da tela A calúnia de Apeles, 1495) e Rubens (Os amores dos centauros, 1635). Isso sem esquecer da escultura, inclusive de nomes contemporâneos do poeta francês e da brasileira, como Rodin, cuja La centauresse, também conhecida como A alma e o corpo, executada em bronze e mármore, de acordo com uma primeira versão em gesso, é datada de 1887-1889, sendo ainda autor de um Torso da centaura.

Menos celebrado, o escultor lionês Augustin Courtet (1821-1890) havia criado muito antes La centauresse et le faune (1849); e, em contexto americano, vale citar, por último, o pintor e vitralista John

\footnotetext{
14 "Em uma pesquisa mais superficial não encontramos referência ao seu feminino, à centaura, em textos sobre a Antiguidade clássica. As referências são relativas apenas aos poemas de José Heredia [...]" (Vicente, 2014)
} 


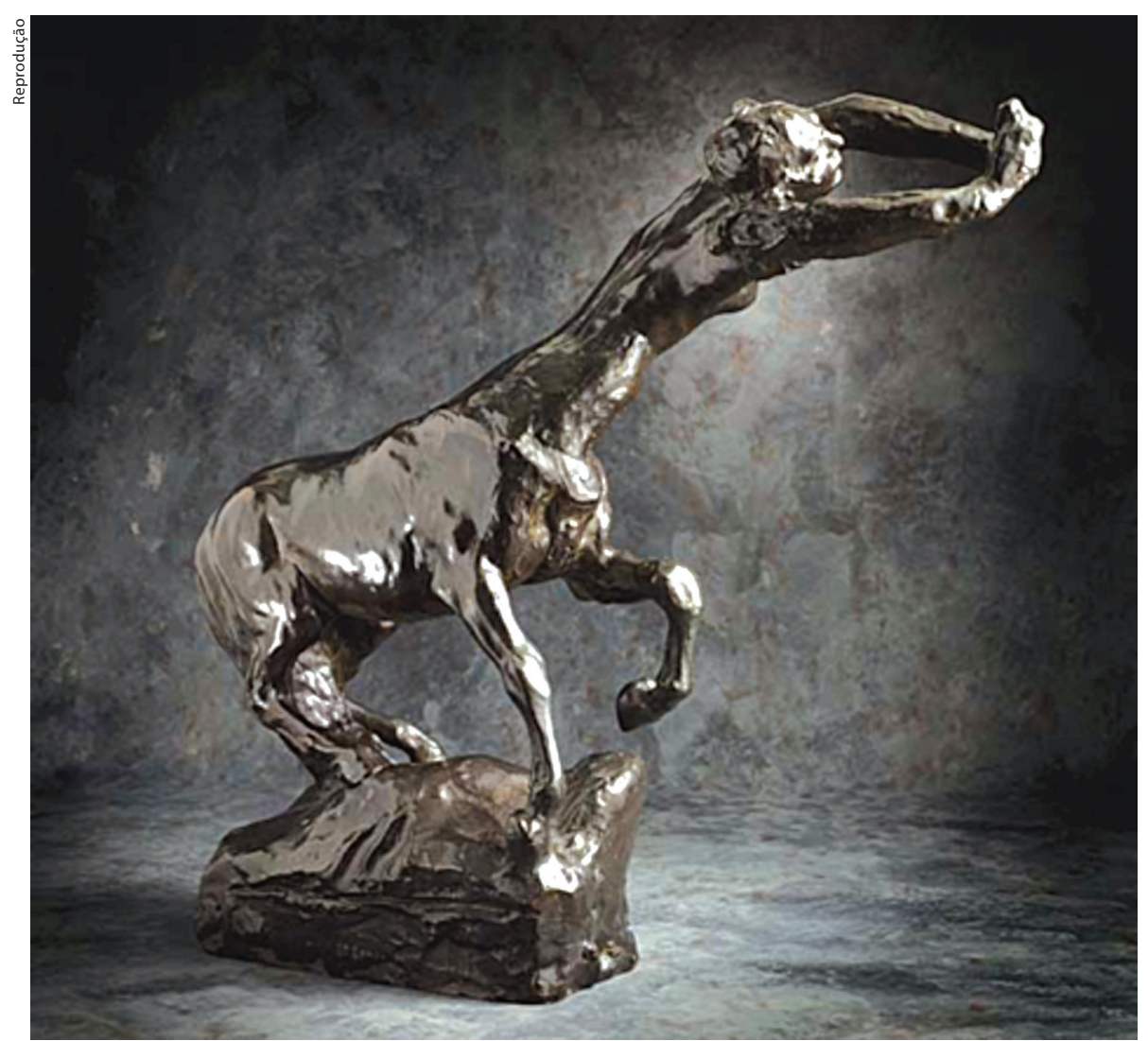

Auguste Rodin, La centauresse, 1887

La Farge (1835-1910) cuja dócil Centauress (circa 1885) está exposta no Brooklyn Museum (NY).

A comparação entre esses exemplos permite algumas observações a respeito da abandonada, solitária e angustiada centaura herediana. Essa condição de solidão pode até ser endossada no caso da escultura de Rodin e na tela de La Farge, embora não, aparentemente, pela situação de abandono. Já nos demais casos, as representações das centauras se dão em situações diversas.

No caso de Rubens, por exemplo, ocorre exatamente o inverso, com os dois casais de centauros flagrados em pleno enleio amoroso e, quanto à escultura de Courtet, a centaura surge como força do-

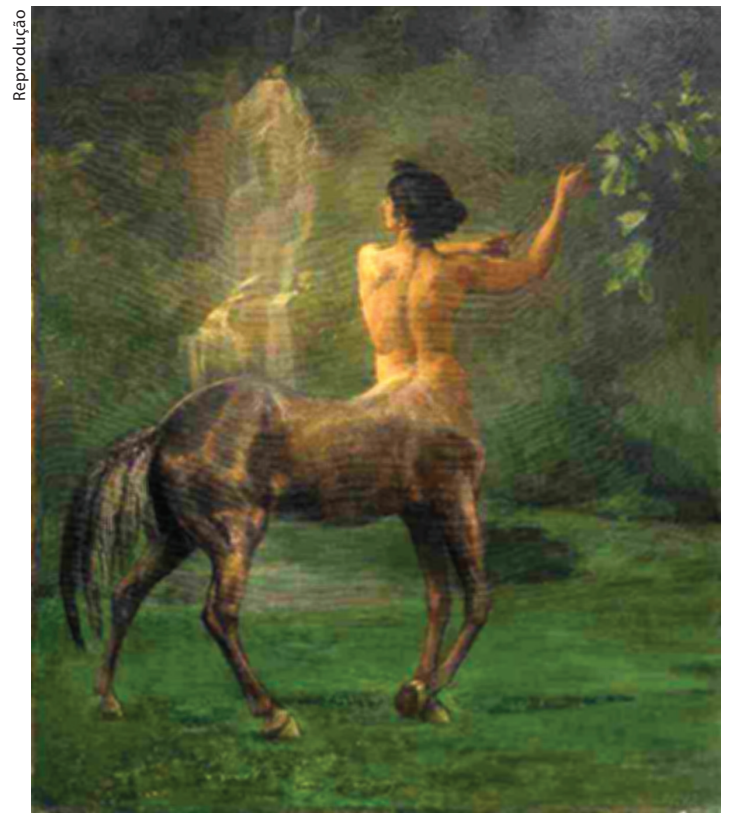

John La Farge, Centauress, ca. 1885, Brooklyn Museum 


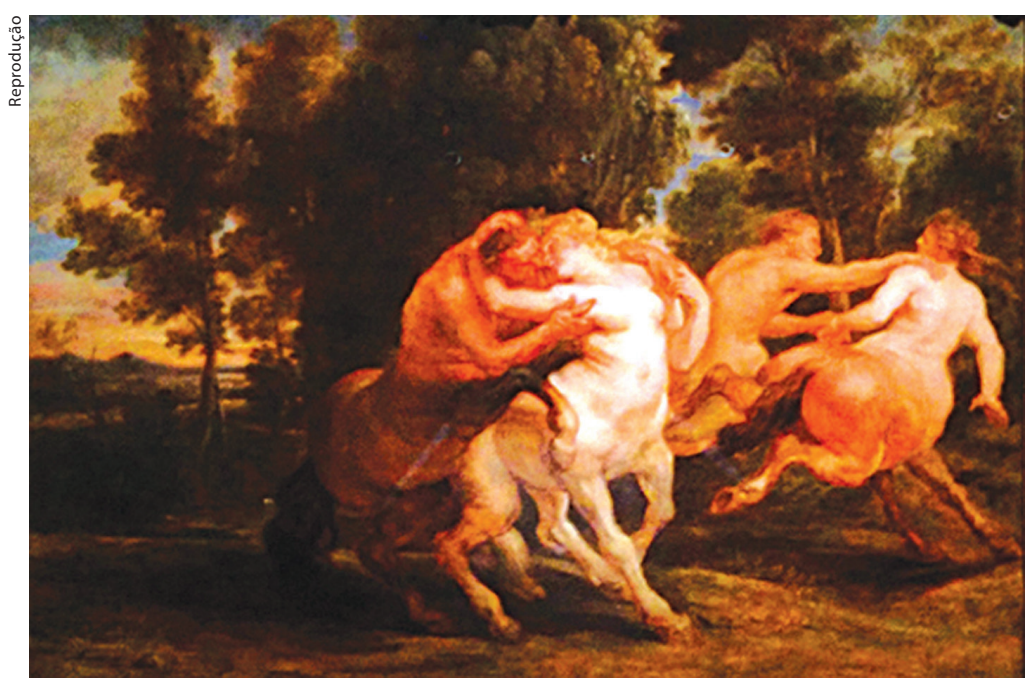

Rubens, Os amores dos centauros, 1635

minadora na sedução da figura masculina, curiosamente representada por outro ser híbrido (embora apareça aqui ainda em sua forma humana), e dos mais libidinosos: o fauno.
Em contrapartida, há o tocante relato ovidiano da trágica história de amor do casal Hilómene e Cúlaro, em que a centaura se suicida com a própria lança que feriu de morte o amado na batalha contra os lá-

Augustin Courtet, La centauresse et le faune, 1849, Parc de la Tête d'Or, Lyon

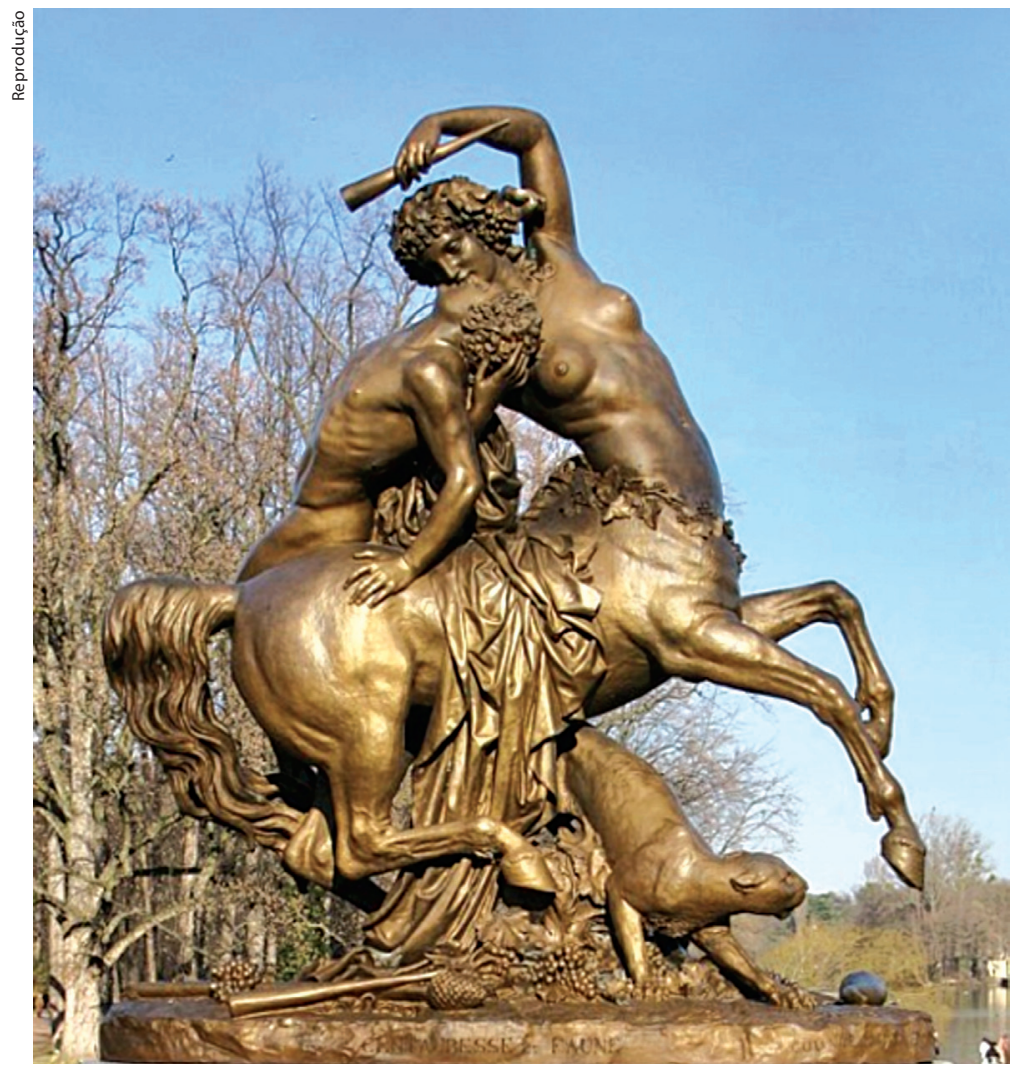


pitas, introduzindo, assim, a nota elegíaca em meio ao relato épico:

"Quem lançou não se sabe, mas eis que um [dardo é disparado da esquerda e crava-se em ti, Cílaro, pouco [abaixo onde o peito sucede ao pescoço. Ao extraírem o dardo, [o coração, atingido por pequena ferida, vai-se esfriando junto

[com o corpo todo.

De imediato, Hilómene toma nos braços o [corpo moribundo, e, pressionando com a mão, tenta acalmar

[a ferida, e encosta os lábios aos lábios dele, e procura travar [a alma que foge. Mas quando o vê morto, com palavras que [o clamor impediu de chegar aos meus ouvidos, deixou-se cair [sobre o dardo que nele estava cravado, e morreu abraçada [ao marido"

(Ovídio, 2007, pp. 210-25).

A condição de abandono e solidão também não marca a tela de Botticelli inspirada no citado relato luciânico, que representa da seguinte maneira uma cena de uma família de centauros:

"Em Zêuxis, Luciano mostra-se contrariado com o fato das demais qualidades do seu diálogo cômico passarem despercebidas ao público, que só tinha olhos para o seu aspecto inovador. Nesse texto, Luciano compara a recepção de um quadro do célebre pintor, cujo nome dá título à obra, com o acolhimento do seu novo gênero [...]. No quadro de Zêuxis, havia uma família de centauros; segundo a descrição de Luciano, a mãe centaura amamentava dois filhotes, um no seio humano, outro em uma teta, como um animal, e, na parte superior do quadro, encontrava-se o hipocentauro pai das duas crianças, não completamente visível, que ria e segurava um filhote de leão para assustá-las. Luciano afirma que Zêuxis buscava sempre fazer algo inédito [...], evitando os temas comuns, e que, quando ele imaginava algo 'estranho' [...], melhor demonstrava toda a sua técnica, mas que também esse quadro, assim como o diálogo cômico, foi louvado graças ao estranho da ideia [...] e à proposta inovadora da pintura [...]" (Sano, 2008, pp. 63-4).

Como se vê, portanto, as situações em que a centaura é representada são bem diversas da de Heredia. Nenhuma delas, entretanto, parece se aproximar da que apresenta Francisca Júlia.

Diferentemente de "La centauresse" herediana, a "Dança de centauras" não traz nem uma figura feminina isolada, nem a condição de abandono e lamento. As centauras de Francisca Júlia não chegam a explicitar seu interesse pelos homens. Pelo menos não no balé encenado. Muito menos se sentem preteridas pelo macho desejoso de se unir a uma mulher tida por superior, porque humana. Pode-se mesmo pensar em certo desprezo pelos homens, na medida em que elas, além de não falarem nada sobre eles, parecem ironizar seu éthos guerreiro.

Mais do que tudo, elas não surgem isoladas, mas em bando ruidoso, alegre, festivo - e esse parece ser seu traço diferenciador. Não ousaria sustentar que essa aparição conjunta é caso único, mas o fato é que tive dificuldades em localizar referências a 


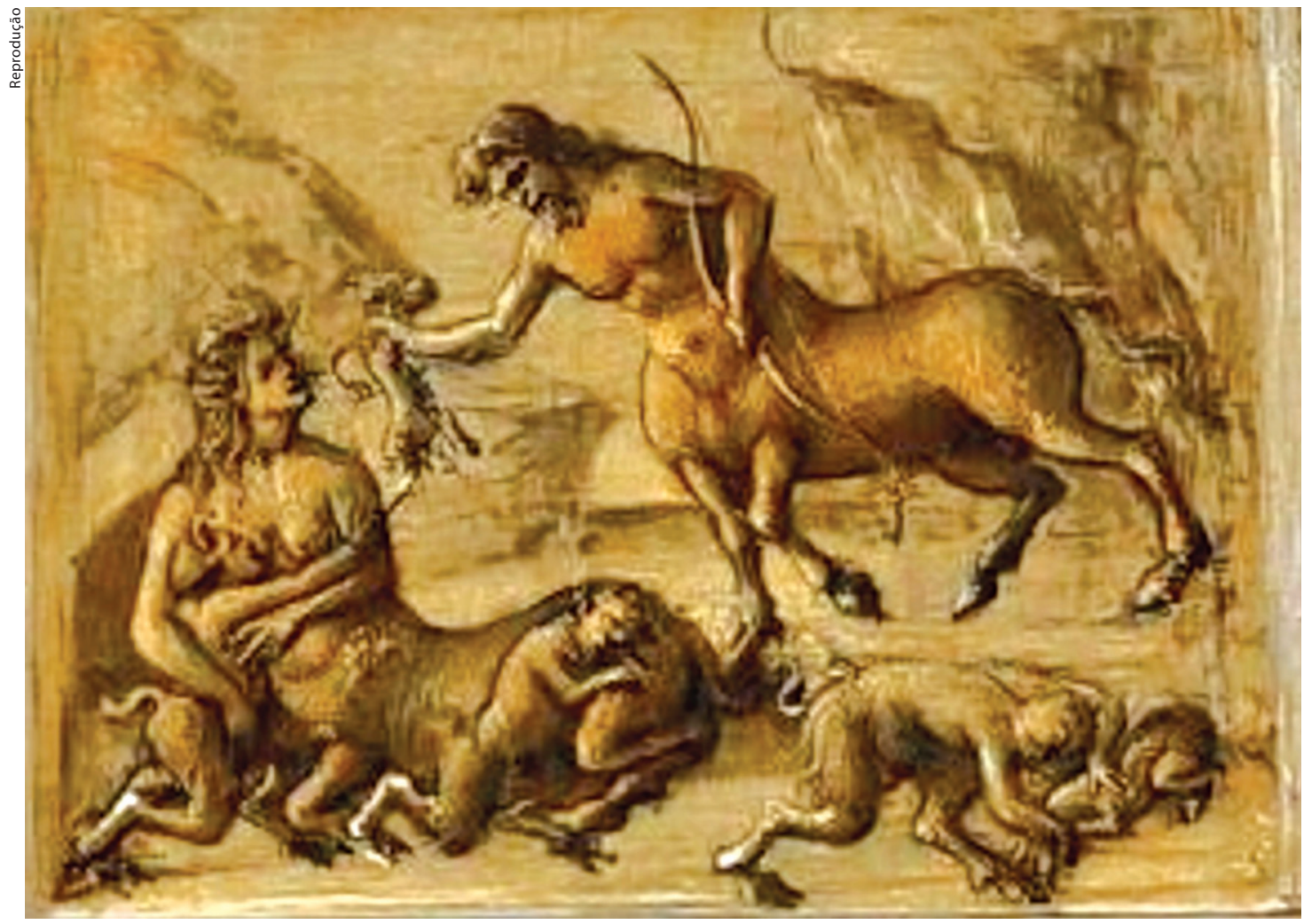

Botticelli, detalhe do frontão do edifício de fundo da tela A calúnia de Apeles, 1495

ela na tradição mítica e artístico-literária ao contrário, evidentemente, do equivalente masculino, com mais frequência representado em bando. Das raríssimas que encontrei na tradição clássica, há a descrição feita pelo retórico grego Filóstrato, o Velho, de uma pintura vista em Neápolis, que apresenta as centauras como irmãs e esposas dos centauros que viviam no Monte Pelião com seus filhos:

"Acreditas que os centauros nasceram de carvalhos, pedras ou mesmo de éguas fecundadas, diz a fábula, pelo filho de Ixião, o que explicaria como se reúnem neles uma dupla natureza: a verdade é que, na espécie dos centauros, as mães sempre tiveram uma semelhança com as mulheres, seus pequenos, com os filhos dos homens, e que tiveram desde o início as estadas mais agradáveis. Não penso, de fato, que tenhas prevenção contra [o Monte] Pelião, contra a vida que se leva ali, contra os bosques de freixos cultivados pelo vento, que dão lanças muito retas, de ponta tão dura quanto o ferro. O que dizer dessas belas cavernas, dessas fontes frequentadas pelas fêmeas dos centauros, semelhantes às náiades, se esquecermos sua natureza equina, lembrando em alguns aspectos as amazonas: é o cavalo unido à mulher, é a força juntando-se à delicadeza das formas. Quanto aos filhos dos centauros, alguns ainda estão deitados em suas fraldas, outros estão começando a sair delas; eles parecem chorar; estes são felizes e sorriem para o seio que lhes derrama leite abundante; outros saltam sobre sua mãe; 
outros abraçam as centáuridas ${ }^{15}$ ajoelhadas; aqui está alguém que em sua insolência precoce atira uma pedra em sua mãe; estes ainda têm apenas as formas indistintas da infância com a carne inchada de leite; estes, que já saltam, mostram não sei que rudeza de modos, apesar da crina que mal desabrocha e dos cascos ainda tenros. Veja também como são lindas as mães, mesmo considerando apenas a parte do cavalo; branco em algumas, castanho em outras, em outras partes de várias cores; todos reluzem com aquele brilho característico das éguas bem cuidadas. Esta, sobre o corpo de cavalo totalmente negro, levanta um busto de uma alvura perfeita: este contraste violento contribui para a beleza do conjunto" (Philostrate L'Ancien, 1881) ${ }^{16}$.

Atente-se a essa brancura perfeita do busto erguido. Será que nossa poeta conhecia o texto de Filóstrato e tenha buscado nessa passagem a inspiração para a ênfase similar dada à brancura dos seios pompeados por suas centauras à luz lunar imagem reiterada no segundo quarteto, que se refere ao fato de elas galoparem livres, com "os peitos cheios de ar"?

Bougot comenta essa passagem de Filóstrato partindo da comparação com a já citada pintura de Zêuxis descrita por Luciano, cuja novidade, segundo ele, era "a dupla amamentação" (uma, humana e outra, à maneira dos potros), representan-

15 Muito embora se encontre em português "centáurida" ou mesmo "centáuride", o Vocabulário ortográfico da língua portuguesa, da Academia Brasileira de Letras, e dicionários como o de Caldas Aulete não apresentam tais variantes.

16 Tradução minha. do "duas maternidades unidas no mesmo indivíduo", que deve ter causado espanto à época. Compara ainda com outras, como a de uma gema ou joia do Museu de Florença, que também traz uma centaura amamentando um pequeno centauro, e a de duas centauras, "que seguram, cada uma, uma pedra em uma das mãos e se preparam para jogá-la" (Philostrate L’Ancien, 1881). Isso só comprova a profusão de representações femininas desse ser híbrido na tradição.

Afora essa aparição clássica, a outra com que me deparei data de muitos séculos depois, em passagem de "Villes", das Illuminations, de Rimbaud: "L'écroulement des apothéoses rejoint les champs des hauteurs où les centauresses séraphiques évoluent parmi les avalanches". Mas tal aparição, além de brevíssima, parece ser uma criação exclusiva, imagem privada, símbolo ou iluminação subjetiva do poeta, sem respaldo nos relatos míticos ou na tradição. Tal verso rimbaudiano é evocado por Bachelard em seu estudo sobre os devaneios, curiosamente para assinalar sua resistência e dificuldade em conceber o feminino de um centauro:

"Por vezes o ato gramatical que confere o gênero feminino a um ser magnificado no masculino é pura inépcia. O centauro é decerto o ideal prestigioso de um cavaleiro que sabe muito bem que nunca será arrancado de sua montaria. Mas que vem a ser a centaura? Quem pode pensar na centaura? Meu devaneio sobre as palavras encontrou seu equilíbrio muito tardiamente. Enquanto lia, devaneando, esse dicionário das plantas que é a Botanique chrétienne (Botânica cristã) do padre Migne, descobri que o feminino sonhador da palavra cen- 
tauro era a centáurea. Pequenina flor, não há dúvida, mas sua virtude é grande, digna do saber médico de Quíron, o centauro sobre-humano. Não nos diz Plínio que a centáurea cura as carnes desconjuntadas? Ferva a centáurea com pedaços de carne e eles serão restituídos à sua unidade primitiva. As belas palavras são já espécies de remédios" (Bachelard, 1988, pp. 29-30).

Em nota de rodapé, Bachelard (1988, p. 30) evoca Rimbaud, observando: "Seja-me perdoada a palavra centauro, pois Rimbaud pôde ver 'as alturas em que as centauras seráficas evoluem por entre as avalanchas' (Les illuminations, Villes). O essencial é evitar imaginá-las galopando planície afora". Ora, foi justamente isso que Francisca Júlia imaginou de forma magnífica!

Nem a clássica versão de Filóstrato, o Velho, nem a moderna de Rimbaud, é certo, podem ser aproximadas daquilo que oferece Francisca Júlia de modo tão fascinante ou mesmo "duma beleza sublime", como queria Mário de Andrade (1974, p. 260) ${ }^{17}$. E fora a beleza e fascínio, essa aparição grupal ou plural, essa multiplicação da figura híbrida feminina dá a impressão de funcionar como índice de algo maior, que alcança o gênero. Volto uma última vez a essa questão.

Emmanuel Santiago (2014) fala, com precisão, em "círculo de uma feminilidade autocentrada, que se faz autônoma em

17 Reforça ainda, depois de dizer que o "autor de Troféus poderia roer as unhas de inveja e escabujar vencido pelo reconhecimento de sua inferioridade", apesar de ter inspirado o assunto à poeta brasileira: "Os vinte $e$ oito versos do francês [referindo-se a "Centaures e Lapithes" e "Fuite de centaures"] não valem os quatorze da paulista" (Andrade, 1974, p. 261). relação ao sexo masculino pela incorporação de características deste", num "clima de liberdade e coragem". Essa "fantasia de um universo feminino autodeterminado", todavia, se desfaz pela presença do sexo oposto encarnado pelo "símbolo máximo de força e virilidade entre os gregos antigos", que é sentida como "promessa de aniquilamento", repondo, assim, "os lugares de gênero". Segundo ainda o intérprete, nada "mais compreensível, considerando o contexto histórico-social de Francisca Júlia, no qual o poder estava distribuído desigualmente entre os sexos e a mulher mantinha-se sujeita à autoridade patriarcal”.

Sem desconsiderar a contribuição relevante dessa abordagem, eu proporia ler a confrontação entre os sexos com ênfase distinta, sem concluir pela mera reposição dos lugares de gênero na ordem e sob as autoridades patriarcais reinantes, que minimizam a força da dança marcial noturna. Afinal, ela não deixa de representar um desafio ou afronta a essa força opressora. Só assim se rompe com a sensação de uma sujeição conformada à distribuição desigual do poder entre os sexos no contexto histórico-social de inserção da poeta. Não veria sentido nos versos sem reconhecer um gesto contestatório encenado pelo bailado noturno, ainda que essa contestação não implique uma investida feminina decisiva contra o opressor. Mesmo a fuga final das centauras não parece simplesmente representar o temor diante da presença ameaçadora da força masculina, pois seu "galope infernal" não deixa de "atroar" o espaço: o verbo é significativo, pois não indica apenas estremecer ou retumbar, mas também aturdir e perturbar... São sugestões sutis, entretanto suficientes para que eu não pactue 
integralmente com a explicação "compreensível" de Santiago. Inclusive causa espécie que ele não veja qualquer nota de erotismo na aparição das centauras e chegue a falar em "recato" de sua nudez... Não consigo reconhecer qualquer recato, ainda mais em vista do contexto de época, na exposição da nudez delas, na ostentação com pompa da alvura de seus seios à luz da Lua e mesmo nos cabelos soltos ao léu, que desde os românticos sempre foram carregados de sensualidade - vide poemas como "Boa noite", de Castro Alves. Há ainda a já destacada ênfase dada aos "peitos cheios de ar". Nesse sentido, parece também ambivalente o fato de Hércules trazer a clava, não empunhada, em gesto de intimidação e ameaça, mas pendente...

Minha interpretação acompanha menos ainda a de João Vicente, quando ele examina a entrada em cena de Hércules, enquanto representação da força da masculinidade impondo restrição à liberdade feminina. Até aqui, pode-se estar de acordo com ele. Todavia, em uma passagem um tanto abrupta, a que parece faltar mediação (ainda que ele fale na "devida modalização"), associa tal força à "universalização do modo de produção capitalista", obrigando os homens a sacrificar o melhor de suas qualidades "para levar a cabo os milagres da civilização que enchem a cidade". Faz derivar de Hércules, assim, não só o ser "organizador" que limita "a algazarra" e promove a "ordem" pela ameaça que se anuncia com sua chegada, mas também a força "hercúlea" (Vicente, 2014) do capital, convertendo de modo forçado o nome próprio em discutível adjetivo.

Há, por fim, que considerar brevemente a transposição dessa oposição de gênero ao plano estético-formal. O imaginário romântico relacionado ao tema da Noite de Walpurgis reaparece no poema não como manifestação extemporânea ou anacrônica de uma tendência estética já suplantada, mas é reinvestida de nova função (de resistência e exortação de um gênero), instituindo uma tensão com a corrente poética então reinante, cujos preceitos temático-formais são associados a concepções reificadas de um dado ideário clássico de que o herói mítico é a expressão mais acabada, aliado a procedimentos como a chave de ouro e a métrica alexandrina, que esse soneto de rimas femininas rigorosamente explora. Tal estrutura rígida parece, de certo modo, perturbada pela variação rítmica, fazendo chocar os dáctilos com que começam, em paralelismo, os versos da primeira quadra com demais pés no interior mesmo dessa estrofe inicial e prolongando-se pelas demais, alternando troqueus, jambos e anapestos, de forma a conferir grande mobilidade ao quadro, em consonância com a irrupção do bailado hípico desse bando fantástico de seres que, em seu hibridismo, rejeitam peias e cabrestos, desde o momento em que chegam garbosas até quando partem em fuga desabalada. 


\section{REFERÊNCIAS}

ANGELLOZ, J.-F. "Henri Heine: un romantique défroqué", in Albert Béguin (org.). Le romantisme allemand. Paris, Cahiers du Sud, 1949.

ANDRADE, Mário de. "Mestres do passado", in Mário da Silva Brito. História do Modernismo brasileiro. Antecedentes da Semana de Arte Moderna. Rio de Janeiro, Civilização Brasileira, 1974.

BACHELARD, Gaston. A poética do devaneio. Trad. Antônio de Pádua Danesi. São Paulo, Martins Fontes, 1988.

BILAC, Olavo. Conferências literárias. Rio de Janeiro, Kósmos, 1906.

CAMILO, Vagner. "Walpurgisnacht e o pandemonismo sertanejo: na trilha do humour noir", in Risos entre pares: poesia e humor românticos. São Paulo, Edusp/Fapesp/ Imprensa Oficial do Estado, 1987.

CARPEAUX, Otto Maria. História da literatura ocidental. Rio de Janeiro, Alhambra, 1987, v. 5 , p. 1.364 .

DELILLE, Maria Manuela Gouveia. A recepção literária de H. Heine no Romantismo português (1844-1871). Lisboa, Imprensa Nacional/Casa da Moeda, 1984.

GANTZ Timothy. Early greek myth: a guide to literary and artistic sources. Baltimore/ London, The Johns Hopkins UP, 1993.

GOETHE W. "Elfenlied/A canção dos elfos", in Poemas. Org. e trad. Paulo Quintela. Coimbra, Centelha, 1979.

GONÇALVES DIAS, Antônio. "Correspondência ativa". Anais da Biblioteca Nacional, vol. 84, 1964. GONÇALVES DIAS, Antônio. "Poemas traduzidos”, in Poesias completas. São Paulo, Saraiva, 1957. GRIMAL, Pierre. Dicionário da mitologia grega e romana. Trad. Victor Jabouille. Lisboa/Rio de Janeiro, Difel/Bertrand, 2003.

HEREDIA, José-Maria de. Les trophées. Paris, A. Lemerre, 1893.

OVÍDIO. "Livro XII", in Metamorfoses. Trad. Paulo Farmhouse Alberto. Lisboa, Cotovia, 2007, pp. 210-25

PHILOSTRATE L'ANCIEN. "III. Les centaurides", in Une galerie antique de soixante-quatre tableaux. Introduction, traduction et commentaire de A. Bougot. Paris, Librairie Renouard, 1881.

RIBEIRO, João. "Prólogo", in Mármores. Brasília, Senado Federal, 2020, pp. 17-8.

ROCHA, Vera Lúcia Figueiredo Costa. "Muse Im (passible)". Revista de Letras, n. 1/2, v. 17. Fortaleza (UFC), jan.-dez./1995, pp. 64-8.

ROSENFELD, Anatol. "Mário e o cabotinismo", in Texto/Contexto. São Paulo, Perspectiva, 1969.

SANO, Lucia. "Das Narrativas Verdadeiras, de Luciano de Samósata: tradução, notas e estudo". Dissertação de mestrado. São Paulo, Universidade de São Paulo, 2008.

SANTIAGO, Emmanuel. "Impassibilidade, frigidez e masoquismo: uma leitura erótica da poesia parnasiana de Francisca Júlia". Texto apresentado no XV Congresso de Estudos Literários da UFES, 2014. Disponível em: http://antenasdemarfim.blogspot. com/2014/01/impassibilidade-frigidez-e-masoquismo.html).

SILVA, Francisca Júlia da. Esphinges. São Paulo, Monteiro Lobato \& Co. Editores, 1921.

SILVA, Francisca Júlia da. Mármores. Brasília, Senado Federal, 2020.

VICENTE, João. "Rigidez escultórica e busca de temática clássica: o rigor formal na poesia de Francisca Júlia". Universitas Humanas, v. 11, n. 1. Brasília-DF, jan.-jun./2014. 